This is an Open Access article, distributed under the terms of the Creative Commons AttributionNonCommercial-ShareAlike licence (http://creativecommons.org/licenses/by-nc-sa/4.0/), which permits non-commercial re-use, distribution, and reproduction in any medium, provided the same Creative Commons licence is included and the original work is properly cited. The written permission of Cambridge University Press must be obtained for commercial re-use.

\title{
Archaeology, Heritage, and Social Value: Public Perspectives on European Archaeology
}

\author{
Kornelia Kajda ${ }^{1}$, Amala Marx ${ }^{2}$, Holly Wright ${ }^{3}$, Julian Richards ${ }^{3}$, \\ Arkadiusz Marciniak ${ }^{1}$, Kai Salas Rossenbach ${ }^{2}$, Michal Pawleta ${ }^{1}$, \\ Monique H. van den Dries ${ }^{4}$, Krijn Boom ${ }^{4}$, Maria Pia Guermandi ${ }^{5}$, \\ Felipe Criado-Boado ${ }^{6}$, David Barreiro ${ }^{6}$, Anita Synnestvedt ${ }^{7}$, \\ Kostantinos Kotsakis ${ }^{8}$, Kostantinos Kasvikis ${ }^{9}$, Eleftheria Theodoroudi ${ }^{8}$, \\ Friedrich Lüth ${ }^{10}$, Mayssoun Issa ${ }^{10}$ and Isabelle Frase ${ }^{10}$ \\ ${ }^{1}$ Department of History, Adam Mickiewicz University in Poznań, Poland \\ ${ }^{2}$ Institut national de recherches archéologiques préventives, Paris, France \\ ${ }^{3}$ Archaeology Data Service, York, UK \\ ${ }^{4}$ Department of Archaeology, Leiden University, Leiden, Netherlands \\ ${ }^{5}$ Institute for Cultural and Natural Heritage, Bologna, Italy \\ ${ }^{6}$ Institute of Heritage Sciences, Santiago de Compostela, Spain \\ ${ }^{7}$ Department of Historical Studies, University of Gothenburg, Sweden \\ ${ }^{8}$ Department of Archaeology, Aristotle University of Thessaloniki, Greece \\ ${ }^{9}$ Department of Primary Education, University of Western Macedonia, Greece \\ ${ }^{10}$ German Archaeological Institute, Berlin, Germany
}

This article presents the key results of a major survey carried out by the NEARCH project on the public perception of archaeology and heritage across Europe. The analysis focuses on three main points of significance for contemporary archaeological practice. The first is the image of archaeology and its definition in the perception of the general public. The second concerns the values that archaeology represents for the public. The third focuses on the social expectations placed on archaeologists and archaeology. The NEARCH survey clearly indicates that there is a significant public expectation by Europeans that archaeology should work comprehensively across a broad range of areas, and that cultural heritage management in general needs to engage more with different archaeological and heritage groups.

Keywords: public archaeology, social engagement, European survey, NEARCH project

Since the 2008 economic crisis, thinking about archaeology and the social sciences has changed. The repercussions of the market crisis have affected academic disciplines as well as the global economy (Schlanger \& Aitchison, 2010). The primary impact on archaeological practice was the cessation of construction work, and underfunding of archaeological projects. In some countries (e.g. Spain and Ireland), commercial archaeology companies which depended on new investments were 
gradually closed and many people became unemployed (Eogan, 2010; Parga-Dans, 2010). In other countries (such as Poland) the quality of archaeological work decreased (Marciniak \& Pawleta, 2010). Today, archaeology and archaeologists find themselves in a new market reality. While the effective communication of the value of archaeology for understanding ourselves and our society has always been important, it has also been greatly magnified by the crisis. Therefore, the ideas championed by the public and community archaeology domains are even more critical within archaeological practice (see Merriman, 2004; Högberg, 2007; Madsuda \& Okamura, 2011; Kajda et al., 2015; van den Dries, 2015). Other factors, such as institutional crises (Marciniak, 2015), denationalization of heritage policy and practice, the growing importance of multinational enterprises (Willems, 2014), greater emphasis on the human rights perspective on memory and identity (Hodder, 2010), or the relationship of heritage to well-being and quality of life (Abel et al., 2010) also have an increased influence on archaeological research. These multifaceted developments have been identified among practitioners in the field as a reflection of more general transformations within society, and have led to a critical assessment of changes in archaeological practice. The interests of the public, however, are often less prominent, or altogether missing, and hence it is difficult to judge how far these trends resonate with public needs and expectations, and more generally to know people's attitudes about the past, archaeology, and heritage. Thus, in some European countries (e.g. the Netherlands, UK, Poland, and France), surveys were undertaken which aimed to study social attitudes to these aspects. Other countries were less focused on issues connected to the societal value of cultural heritage and archaeology. Therefore, such approaches within archaeological practice are still needed. As Olivier (2015: 14) states: 'This must take us far beyond defining the ways in which archaeology can contribute to society $[\ldots]$ to acquiring a much better understanding of what society wants from archaeology and from archaeologists.'

The first European study to approach the issue on a larger scale is the survey conducted by Harris Interactive on behalf of the NEARCH: New Scenarios for a Community-involved Archaeology project. It is a wide-ranging study that offers a significant opportunity to address the meaning of archaeology and heritage to the European public in a comparative, quantitative, and qualitative way. The aim of this article is to present its main results. Because the NEARCH survey provided a huge amount of data, the results are examined here in their broader context. More detailed and regional analyses will follow.

The purpose of the survey was to identify public perceptions of archaeology and archaeological heritage, and public expectations of archaeology. The survey was conducted in nine European countries: Germany, Greece, France, Italy, the Netherlands, Poland, Spain, Sweden, and the UK (the partner countries represented within $\mathrm{NEARCH}$ ). Although such studies have been undertaken previously at the national level, this survey is the first to be based on a cohesive methodology, with a comparative group of respondents across Europe. The 4516 people who participated in the survey have provided a broad insight into what European citizens think about archaeology, how they understand and valorize heritage and knowledge of the past, and a clear view of interest in these topics within Europe.

This article will focus on three main results from the survey. The first is the image of archaeology and its definition as understood by the public. The second concerns the importance of archaeology within society and the values it represents. 
The third concentrates on the expectations of archaeologists and archaeology by society.

\section{Overview of the National Surveys on the Public Perception of Archaeology and Cultural Heritage}

In many European countries, an analysis of the meaning of archaeology and archaeological heritage has been undertaken only recently. These early studies (discussed below) may be treated as a sign of the growing need for the democratization and popularization of knowledge. Taking into account the differences in approach when studying the social perception of archaeology, several aspects of the national surveys are presented from which interesting points about the social value of heritage, archaeology, and the past may be explored.

\section{Previous national surveys about the archaeology sector in Europe}

National surveys within the NEARCH partner countries have been conducted on large and small scales, depending on the country and the purpose of the study. The first of these studies was conducted in the Netherlands, twenty years before the NEARCH survey. In the 1990s the Dutch archaeological sector carried out a large public survey (NIPO/AIC, 1996). Through interviews and questionnaires, nearly 3850 citizens were asked about their knowledge, attitude, and behaviour in relation to Dutch archaeology. The Netherlands also carried out smaller studies conducted by the Archaeological Heritage Management chairgroup of the Faculty of Archaeology (Leiden University) and its students. These included mainly small, local target groups (e.g. van den Dries \& Van der Linde, 2012; van den Dries, 2014; van den Dries et al., 2015).
Similarly to the Netherlands, various surveys on public attitudes towards archaeology and heritage have been conducted in the UK. The last large-scale national survey of attitudes to heritage was conducted in 2000 (MORI, 2000b), on behalf of English Heritage, for the seminal Power of Place report (English Heritage, 2000). This report has been seen as marking the introduction of an explicit audit culture to the historic environment sector, which was later extended to Scotland (Baxter, 2009: 91).

In Spain, the first survey of this kind was carried out in Madrid in 2006 (Almansa, 2006) on a sample of 150 people, with the aim of discovering the opinions held by the local population regarding archaeology and its social usefulness. A more recent example is that of a survey conducted in Seville in 2012 on a sample of 450 people, which focused on perceptions of urban archaeology and archaeological heritage among the inhabitants of the city (Ibáñez, 2013). The study, undertaken as part of the Programme on the Preventive Conservation of the Altamira Cave (Incipit, 2014), is a second recent example. In this, the Institute of Heritage Sciences (Incipit-CSIC) conducted a survey at the Museum of Altamira in northern Spain on a sample of 1028 people, which included general questions regarding perceptions of cultural heritage. A remarkable result of this survey was the divide between those visitors who think that cultural heritage is 'something that represents the identity of a people' (37 per cent) and those who consider it 'something worthy of being preserved according to the criteria of experts or politicians' (31.4 per cent). In other words, people are divided between those who consider heritage as something that represents them and those who believe that scientific criteria should determine whether something deserves to be preserved or not (Parga-Dans, 2014). 
In Poland and France, the study of public attitudes to archaeology and heritage occurred alongside the professionalization of archaeology, which is closely linked to the birth of preventive archaeology. This professionalization generated the need to disseminate archaeological knowledge, as well as the methodological and scientific processes that lead to such knowledge creation (Kaeser, 2016).

In 2010, the French National Institute for Preventive Archaeological Research (Inrap) launched a survey conducted by Ipsos (De Sars \& Cambe, 2010) on the image of archaeology among the general public, following a 2006 study on this theme (Salmona, 2008: 120-23). In 2012 and 2014, France conducted surveys on archaeological museum visitors (Jonchery \& Dezellus, 2014), providing information on public profiles. Research was also conducted by Inrap during the National Day of Archaeology (in 2014 and 2015-analysis ongoing) which will offer detailed information on visitors and their expectations of their archaeological visits.

In Poland, a few systematic studies of the subject were conducted between 2010 and 2013 (see Kozioł et al., 2013; Kajda \& Kostyrko, 2016). These were small-scale studies, concentrating mainly on local communities and their perception of heritage.

In Greece and Germany, no central state initiative has attempted to measure and valorize the impact of archaeology for the public on a national scale, but surveys have been undertaken on a regional or local scale as part of research conducted by universities and archaeological associations (Kotsakis et al., 1993; Sakellariadi, 2011; Kotsakis et al., 2015) or through studies concerned with the impact of archaeological fieldwork on local communities (see, e.g., Bohne \& Heinrich, 2000; Hodder \& Doughty, 2007; Kotsakis et al., 2007; Stroulia \& Sutton, 2010).

In Italy, statistical surveys regarding archaeology have focused almost exclusively on aspects related to the archaeological profession. They have thus been 'internal' analyses, conducted mainly by professional associations within the sector. The only surveys on a national scale consist of quantitative data, such as the number of visitors/users of cultural institutions (MiBACT, 2014), which are currently limited to museums and archaeological sites (MiBACT, 2016), while institutions which do not generate revenue through admission charges (libraries and archives) have been excluded. Studies of greater breadth have been carried out, albeit not very recently, on museums and their visitors (Solima, 2000) or cultural tourism (Centro Studi TCI, 2002), but the specific subject of archaeology cannot be distinguished within these studies.

The same situation applies in Sweden where surveys exclusively focusing on archaeology have not been undertaken so far. Instead, questions related to archaeology have been embedded in polls addressing broader perspectives about heritage. Between 2001 and 2004, several surveys were undertaken, at both national and regional levels, connected to the project Operation Heritage (Agenda Kulturarv). The aim was to produce a policy statement-an agenda for the cultural heritage-'Putting people first', which was launched in August 2004 (Agenda Kulturarv, 2004). The main survey was carried out by Statistics Sweden (SCB) in 2002 on behalf of the National Heritage Board. The aim was to investigate the public's interest in, and knowledge of, the cultural environment (RAÄ, 2002). Two thousand people between the ages of 18 and 74 completed the questionnaire. In 2003, another poll was undertaken in the region of West Sweden by the SOM institute about attitudes towards heritage in the region (Blank, 2003). This poll was much inspired by the investigation Attitudes towards the Heritage undertaken by English Heritage during 2000 (MORI, 2000a). 


\section{Perception and meaning of archaeology in the national surveys}

The picture which emerges from the national surveys is that most European citizens view archaeology and heritage in a positive way. Among Dutch respondents, 56 per cent believed archaeology is valuable. In Greece, the great value of archaeological heritage (including archaeological sites or monuments, or an ongoing excavation) was also widely understood.

One of the main results was that there was also wide public interest in taking part in heritage-related activities. In Sweden, more than 75 per cent of the population goes at least once or twice a year specifically to visit a cultural environment, a museum or cultural building. In the UK, 51 per cent of the population had visited a historic attraction, compared with 50 per cent visiting the cinema and 17 per cent attending a football match. In the British surveys, more than half the respondents said they were as interested in learning about other people's cultures as their own.

In both countries, surveys concluded that a major task for the cultural heritage sector was to increase interest within groups that are currently underrepresented. In the survey conducted in western Sweden, 57 per cent of respondents thought there was a need for more and better information about heritage (Aronsson, 2003: 68-80; Blank, 2003; Synnestvedt, 2008: $33)$. In the UK, people representing ethnic minorities wanted more to be done to make the historic environment accessible to them through information, more inclusive interpretation, and education. In 2003, MORI examined some of these identity issues in a follow-up study focusing on case studies in Bradford, Cornwall, and West London, revealing a high level of regional variability (MORI, 2003).

In France, however, the public was more interested in history (38 per cent) than in archaeology itself (19 per cent), but still considered archaeology useful (85 per cent). A lack of information about archaeological excavations was flagged up: 77 per cent of respondents felt insufficiently informed.

Despite the universally recognized need for improved dissemination of archaeological information, interest in engagement in archaeological projects was often even less noticeable in the responses. In some countries respondents exhibited very limited motivation for participating in actions connected with heritage protection, or even visiting sites. In the Netherlands, 60 per cent of respondents did not participate at all. Those who did participate were mostly male, aged 45 and above, with a high level of education and living standard. The later studies observed a slight increase (more visitors) between 1996 and 2007, but primarily within the same segment of the public. In France, public participation in archaeological practice gradually declined as archaeological regulations and the professionalization of archaeology grew (Depaepe \& Salas Rossenbach, 2013: 129-36).

When it comes to the meaning of heritage and its role in society, the studies revealed that the most important role of heritage and archaeology is connected to its educational value. In the UK, the MORI survey found that almost everyone believed the historic environment plays an important role in the life of the country. Above all, people considered the historic environment to be vital for educating children and adults about the past. The poll found that 95 per cent thought that heritage is important for providing places to visit and things to see and do, for encouraging tourists to visit (93 per cent), and for creating jobs and boosting the economy (88 per cent). The great majority of people (88 per cent) believed that public funds should be used to preserve 
historic buildings. Three-quarters agreed that it is important to preserve rare modern buildings as well as the old.

In Greece, the public appreciates archaeological heritage primarily for its historical value and for increasing knowledge of the past. However, the studies in Greece revealed two tendencies: on the one hand the official appreciation of archaeological heritage as part of the official discourse about the past, while, on the other hand, regional excavations have little historical value in building up the local, collective memory (Sakellariadi, 2011: 116).

In Poland, the surveys revealed that Polish people perceive archaeology as a science useful for discovering the human past, and typically associate it with excavations (Kobyliński, 2009; Marciniak, 2011; Marciniak et al., 2011; Pawleta, 2016). People recognize it as relevant, believing that archaeologists bring the past closer to modern society, and help local communities to understand it. Moreover, Polish people often associate archaeology not only with the distant, but also with the recent past (Kajda \& Kostyrko, 2016). Polish studies also indicate that cultural heritage is seen as a product that may positively affect social and economic reality on a local and national scale (e.g. through tourism). The public considers itself stakeholders in the decisionmaking process concerning heritage management. The majority of the respondents were of the opinion that it is worth investing public money in heritage, yet no sense of public responsibility for heritage is evident; rather it is seen as the task of historic preservation officers and state bodies (Kozioł et al., 2013: 86-87).

In summary, these regional and national surveys give some important insights into differences in public attitudes to heritage and archaeology across Europe, but they do not provide a truly comparative perspective since different methodologies were employed in each case. However, the regional and national surveys provided a basis for the NEARCH survey which aimed to study the public outreach of heritage and archaeology using a coherent methodology.

\section{Methodology}

The NEARCH survey was conducted by the Harris Interactive Research Agency according to their standard polling methodologies. This was a quantitative study that was conducted on 4516 adults, aged 18 or older across nine European countries (a sample of c. 500 people by country) from 29 December 2014 to 6 January 2015. It was conducted online, based on panels employed by Harris Interactive and Toluna, using a computer-assisted interviewing system for multiple media (web, mobile phone, tablet). Respondents were contacted via an invitation email asking for responses to a questionnaire consisting of twenty-eight questions, which required a time commitment of about 15 to 20 minutes.

\section{Design of the questionnaire}

The questionnaire was designed by the NEARCH partnership according to their various interests in collaboration with Harris Interactive. The first part of the questionnaire was intended to interrogate respondents on their knowledge, interest, representation, and involvement in archaeology; the second part was designed to measure their perception of archaeological management and financing.

Initially constructed in French and English, the questionnaire was then translated into the seven languages of the other countries screened. This translation was carefully checked; first by Harris Interactive translators specialized in survey translation, then reviewed by each 
NEARCH partner in their native language to refine any words or notions difficult to translate.

\section{Sample frame of the population interviewed}

The Harris Interactive and Toluna panels are currently known as the most reliable and representative sample of population. They comprise 9 million members across the globe, of which 2.5 million members reside in Europe. The representativeness of the samples used for the study is determined by socio-demographic criteria based on the European common base 'Eurostat' that offers transverse criteria across different European countries: gender, age, social professional category, and region. For each country, a population of 500 people was interviewed (except for 516 in Greece to reach a representative sample of the population). This sample size is considered by survey specialists to be sufficient to allow countrywide representative results. ${ }^{1}$

\section{Processing of the results}

At the end of the fieldwork, adjustment methods were used to overcome potential differences between the representativeness of the socio-demographic criteria (quotas) and the sample frames in each country. For this study, adjustments were extremely low because the respondent samples were already very close to the population as a whole. Answers to the open questions were analysed to identify themes frequently addressed. A codification plan was then implemented and applied to the set

1 In 17 countries, Harris Interactive conducted a survey for Accenture, with a population sample of 500 people per country, as well as for Axa Assurance in five European countries, using the same population sample size. of answers. This guarantees a similar treatment and the possibility of sorting according to variables. This produces statistical results similar to those for closed questions.

\section{Social Perception of Archaeology and Heritage}

What follows is a summary of the results of the NEARCH survey from the participating countries (Martelli-Banégas et al., 2015). In the discussion section, the overall results are compared with the corresponding results for each country.

\section{The image of archaeology in society}

Four of the twenty-eight survey questions refer to the public perception of archaeology-especially its definition and categorization within knowledge and professional fields, as well as how it is managed and financed. The first question asks for a spontaneous definition of archaeology. In the majority of answers, archaeology is seen as a way of studying the past through excavations (digging). Most respondents (48 per cent) defined archaeology as relating to the analysis of the past, and 37 per cent said that archaeology is connected to digging/excavations.

With regard to the image of archaeology in society, respondents were asked whether they see archaeology more as a science, an area of knowledge, a profession, a cultural activity, a skill, a leisure pursuit, or if they do not connect archaeology to any of these aspects (respondents could choose two answers). Most participants stated that archaeology is a science (69 per cent) and an area of knowledge (39 per cent), while some indicated that archaeology is a profession (26 per cent) or even a cultural activity (25 per cent). 
The way archaeology is managed is another important aspect addressed by the survey. Who should be responsible for its management and funding? The majority (65 per cent) indicated the State should be responsible, while only 14 per cent said not. Moreover, even more respondents indicated the State should fund archaeology (75 per cent); many also mentioned the private sector and other sponsors (44 per cent), and 40 per cent regional governments.

\section{The value and importance of archaeology within society}

Five questions referred to the significance of archaeology and heritage within society, and the values ascribed to both. Respondents were asked about the current importance of archaeology to them. Archaeology was seen as having great value (91 per cent) to society and being useful (90 per cent), enthralling (87 per cent), moving (81 per cent), and relevant to modern life (76 per cent). Thus, most Europeans have a positive image of archaeology. Respondents said it teaches society about the past (75 per cent) and facilitates knowledge of the past being passed down to future generations (47 per cent). This seems to indicate that the importance of archaeology stems from how it relates to identity. A strong link with the legitimization of one's presence in a place is visible in the answers. Forty per cent of respondents stated that 'archaeology is a field of knowledge which helps to understand our place in the world', suggesting that there is a strongly perceived value of archaeology in the present. Forty-six per cent of respondents indicated that archaeology also facilitates 'understanding the past to better prepare for the future'. Archaeology is perceived as a pragmatic field of knowledge. That archaeology is advantageous to society is additionally confirmed by responses which indicate that 'archaeological remains are perceived as an advantage for a town' (stated by 86 per cent of interviewees), that 'supporting and developing archaeology is important for my country' (83 per cent), and that 'a citizen should have some knowledge in archaeology' (73 per cent).

\section{The role of archaeology for the public}

Because the NEARCH survey also concentrated on the future of archaeology in society, three questions referred directly to the expectations which society has towards archaeology. By asking what is important to develop within archaeology and is of particular interest to the public, the intention was to understand societal needs in terms of outreach activities.

The most common response concerned issues connected with preventive archaeology (development-led archaeology). Most respondents stated that construction should be postponed when archaeological remains have been found. This suggests that, for the majority, the protection and rescue of heritage is more important than the pace of development. Other answers primarily stressed the need to disseminate knowledge about archaeological projects, the profession, and heritage generally. The respondents also noticed that in many museums there is too little attention paid to archaeology (58 per cent).

The desire for a stronger democratization of archaeological knowledge is also clearly evident in the responses about the ways in which respondents would like to interact with archaeology and heritage. The most popular answer was related to visiting archaeological sites (85 per cent), and many respondents also indicated that they would like to meet 'archaeologists to better understand archaeology's usefulness for my local community' (62 per cent) or 'meet them to better understand the archaeological profession' (61 per cent). People 
mentioned they would like to take part in archaeological excavations (61 per cent) and attend a conference where they would get more information about archaeology (52 per cent). More than half stressed that they would like to be involved in the decision-making process surrounding archaeological projects in their local area (51 per cent).

\section{Discussion of THE Results}

The NEARCH survey gives insight into the general attitudes of Europeans towards archaeology and heritage, as well as diversity among countries and regions. It also highlights problems which affect archaeology generally and give the profession the opportunity to evaluate, redefine, and change actions taken within the archaeological and heritage sectors. The following section discusses the three main points of the study on a European and national scale.

\section{The image of archaeology in society}

The public image of archaeology is that it centres on research about the past and that it uses a particular research method, namely excavation. For 37 per cent of respondents, archaeology is linked to digging, and it seems that for many people this is what differentiates archaeology from other fields of knowledge that deal with the past.

The most overarching understanding in this part of the survey related to the perception that archaeology is a science (the European average is 69 per cent of responses). However, the study also reveals some striking differences in the perception of archaeology at a national level. In Greece and Germany, respondents strongly linked archaeology with the scientific world (88 per cent and 82 per cent respectively), but in the UK only 46 per cent of citizens saw it as a science, although this may also reflect different usage of the term 'science'.

In France, respondents show a growing knowledge about archaeology. In the national survey, 78 per cent of French respondents defined archaeology by its operating method (excavation), and only 10 per cent as the study of societies; but in the 2015 NEARCH survey, 50 per cent defined archaeology as a science that analyses the past.

The connection of archaeology to the world beyond academic institutions and universities is understood by the European public. Archaeology is seen as cultural activity, linked to taking part in archaeological events and visiting archaeological sites, by 25 per cent of Europeans (although less so in Poland (14 per cent) and the Netherlands (17 per cent). Understanding archaeology as a cultural activity may be the result of the growing number of actions in which archaeology and knowledge about the past are presented as entertainment (Pawleta, 2016). Furthermore, the influence of developerfunded archaeology and rescue excavations is apparent in the results. Defining archaeology as a profession (26 per cent being the European average) indicates the popularity of, and knowledge about, preventive archaeology. However, in Greece, where only 13 per cent of respondents defined archaeology as a profession (despite 88 per cent of Greek respondents indicating it was a 'science'), shows that it is still strongly linked with academic rather than development-led practice.

Focusing on the State as the main institution responsible for managing archaeology (65 per cent as the average across the survey) and financing archaeology (75 per cent), on the other hand, stresses that the public perceives archaeology to be a science/area of knowledge existing outside the market, relying solely (or mostly) on 
national or European funds. The same is revealed when looking at awareness of who undertakes archaeological research. Most responses indicated universities (73 per cent) and public research institutions (66 per cent). In the UK, however, more than three-quarters of people surveyed believed it is undertaken by museums; the role of the amateur sector (such as detectorists) is also quite pronounced (78 per cent of responses compared to 55 per cent as the European survey average). Moreover, half believe 'archaeological associations' manage archaeology, while less than a third believes it is the responsibility of national or regional government. Most tellingly, only 40 per cent believe it is the State's responsibility to manage archaeology, compared with the European survey average of 65 per cent. This variation in perspectives may be related to the different organization of archaeology in the countries studied.

In Greece, the management of archaeological heritage is primarily considered to be a responsibility of the State (72 per cent) and this reflects the predominance of the State as the only agent of heritage management. At the same time, people in Greece are highly critical of heritage management in comparison to other Europeans. This high percentage of criticism reflects overall disappointment, i.e. a lack of efficiency by the State, something highlighted as being also due to the economic crisis.

Similarly, 86 per cent of Italians surveyed believed the management of archaeology should be the responsibility of the State. This very high percentage (the European survey average was 65 per cent) reflects the actual administrative situation, in which a government authority-the Ministry of Cultural Heritage-has a monopoly over the management of archaeological heritage. Additionally, the recurring news stories about the deteriorating condition of archaeological sites (e.g. the collapse of the House of the Gladiators in Pompeii in November 2010; Erbani, 2015) explain why 90 per cent of Italians judge efforts to protect the archaeological heritage to be insufficient.

In Spain, the vast majority (76 per cent) believe archaeology should be the responsibility of the State, although the importance given to the role of regional governments in Spain is higher than the European average. In a national survey (García, 2012: 89-90), 90 per cent of people believe it should be the responsibility of the public administration, whereas 20-25 per cent believe foundations, the Catholic Church, and individuals should be responsible. Therefore, it appears that the population supports a view that archaeology and heritage are the responsibility of the State (though in the case of the Seville survey, the percentage drops to 67 per cent; Ibáñez, 2013: 98).

\section{The value and importance of archaeology within society}

The NEARCH survey shows that the importance of archaeology is growing within society. On the European survey level, 91 per cent of respondents indicated that archaeology has great value, and 90 per cent classified it as useful. The majority of respondents stated that they have an interest in archaeology, and appreciate visiting museums and archaeological sites. This may be explained by the increasing number of projects and actions (such as archaeological festivals) which encourage the general public to take part.

On a national level, there were some differences in the social attitudes towards the values archaeology represents. The survey highlights, not unexpectedly, an affinity between Italy and Greece, whose inhabitants have a closer relationship with monuments and sites of the Classical 
period (over 90 per cent) than the average European (about 70 per cent), and shows a particularly strong attachment to archaeology compared to other countries.

For the Netherlands, some very positive developments have taken place since the first survey in 1996. The NEARCH survey shows that currently more respondents are acquainted with organizations offering knowledge and outreach activities (from 65 per cent in 1996 to 80 per cent in 2015), such as the National Museum of Antiquity (from 45 per cent to 72 per cent) and the theme park Archeon (from 55 per cent to 80 per cent). Additionally, visitor numbers have increased and the overall opinion about the value of archaeology has improved: in 2015, 89 per cent of respondents believed it is useful and of great value (compared to 56 per cent in 1996).

Likewise, in France respondents also show a strong interest in archaeology: 58 per cent have a special interest in the subject, which is comparable to a study conducted in 2011 on archaeological sites and museum visitors (Dezellus \& Germain, 2014). A significant attachment to the discipline was also pointed out in the new survey (63 per cent in France, 54 per cent in Europe), and the feeling of usefulness already shown by the two studies of 2006 and 2010 (85 per cent) was confirmed in 2015 (89 per cent).

In Sweden, the NEARCH survey shows that there is a lower participation in activities linked to archaeology among young people and people in lower socio-professional categories, while among seniors and those in upper socio-professional categories, the perception of archaeology is much more positive, and knowledge of sites and museums is much higher. This confirms the picture given by previous national surveys and indicates little change since 2002-2003.

The significance of archaeology for European society relates to its ability to communicate. According to the NEARCH survey, knowledge of the past, especially the origins of humanity and its evolution, and of the lives of ancestors, is highly appreciated by European communities (75 per cent). In Poland, this is especially pronounced, as 93 per cent stated that archaeology is important because it helps people know where they come from and learn more about their past. However, this very positive attitude towards archaeology is shown mostly by people aged 35 and older, while younger people are less positive when it comes to valorizing archaeology. The main role attributed to archaeology in Poland is education, with 57 per cent, more than the European survey average (44 per cent), indicating that teaching the history of Poland is one of the main roles of archaeology. In Poland, history, and therefore archaeology, is considered as playing a vital role in passing knowledge to younger generations.

In Sweden, the NEARCH survey revealed interesting differences between age groups. When asked what the role of archaeology is, 37 per cent of those aged between 18 and 24 considered passing history down to younger generations as important, compared to 62 per cent of those between 45 and 59 years old. A variable within this question asked whether archaeology contributed to quality of life. Here there is a change in positions, as 11 per cent of younger people found this valuable, compared to 3 per cent in the older group. This may reflect different ways of teaching archaeology and history in Swedish school education. The older generation may have focused more on fostering and learning about history to be a good citizen. The younger generations may be more selforiented and interested in questions of lifestyle and what is valuable for their personal development.

In the UK, only 26 per cent thought archaeology was important for understanding 
where one comes from, whereas the figure for Europe is 52 per cent. As might be anticipated, there was also less support for archaeology as a means of uniting citizens around a common cultural heritage (only 14 per cent of UK citizens compared to 19 per cent of Europe average), whatever their origin, or for contributing to the construction of European citizenship (3 per cent compared to the 5 per cent European average).

In Greece, more than other European countries, archaeological heritage is considered important in both an ideological and an economic context. The high valorization of Classical antiquity is particularly strong compared to the European average (60 per cent as opposed to 27 per cent across the European survey). This is attributable to the dominance of Classical antiquity throughout the education system but also to the official discourse and the trajectories of national self-consciousness. The significantly smaller percentage, in comparison to the European average, of appreciation of Middle Ages and modern periods may mean that in Greece people do not consider the medieval past as archaeological heritage, or they do not value it to the same extent as Classical archaeology.

In Italy, in several points, the survey underscores the connection between archaeology and tourism, considered to be one of the main objectives of the discipline in view of its economic implications. This link has also been emphasized at a political-administrative level, given that the Ministry of Cultural Heritage has also inherited, in 2013, responsibility for tourism. Moreover, since the 1980s, both in the media and the political realm, cultural heritage has been assumed to be a major economic resource (Montanari, 2015).

A new perspective for archaeology and its value is also indicated by the NEARCH survey. Linking archaeology to the present and the future, and noticing its usefulness in terms of better preparation for the future (46 per cent as the European average), is an important aspect to be developed within archaeological projects. This tendency is especially visible in Germany and in Sweden, where 56 per cent indicated that this was of value. Although the percentage is not as high as for other questions, it is still positive and significant that European society perceives that archaeology may contribute to the quality of life and general development.

\section{The role of archaeology for the public}

The results of the NEARCH survey show that archaeology is significant to society. Moreover, the public wants knowledge about archaeology to be communicated in an accessible way, and to participate in actions connected to heritage. In general, the European survey indicates that the public wants greater involvement in archaeology, through visiting archaeological sites (85 per cent), meeting archaeologists to better understand archaeology's usefulness for their local community (62 per cent), or taking part in excavations (61 per cent). The majority of respondents (71 per cent) expect archaeologists to better disseminate their results and create more possibilities for cooperation. This open approach to archaeological knowledge demonstrates that society has positive connections to archaeology, and that it is time for archaeologists to engage society with their actions more effectively. However, some differences between engagement in archaeology and expectations about it are visible at a national level.

Italy expressed a high level of interest in archaeology, and a desire for more information about it (86 per cent, compared to the European average of 69 per cent). This wish for better communication might 
be explained by the fact that museums and archaeological sites in Italy are struggling to update facilities, and therefore not succeeding in involving the general public as they might wish.

Another nation expressing a strong interest in archaeology are Poles. Most Polish citizens engage with archaeology in some way. The majority (89 per cent) watch films about archaeology, visit archaeological landscapes (73 per cent) or exhibitions (72 per cent), read books or magazines about archaeology (68 per cent), or even take part in archaeological excavations (14 per cent). Moreover, a large proportion (90 per cent) perceive archaeological heritage as advantageous for towns and as something that should be supported and developed (82 per cent). Responding to this need is still developing among archaeologists in Poland. Seventysix per cent of the people polled recognize that there is too little knowledge dissemination around archaeological finds, and 77 per cent also state that there is too little information about how the public can engage with archaeology.

Sweden is similar, and with only 60 per cent of young people aged 18-24 responding in the NEARCH poll that it is valuable to have archaeological remains in their town. This means that better heritage management strategies and information programmes are needed. This result should be compared with the fact that 77 per cent of younger people would like to visit an archaeological site, and this rises to 90 per cent for people aged 35-44. Again, these results indicate information and interpretation programmes are needed to make archaeology more visible in society for younger generations.

In Spain, more emphasis is placed on the protection of heritage than on the dissemination of knowledge. This is apparent in the NEARCH survey, as well as in the study carried out in Seville, in which 60 per cent of respondents argued that the archaeological heritage must be preserved even if it cannot be physically enjoyed (Ibáñez, 2013: 98). Therefore, it seems that the idea of heritage conservation being a social necessity is defended by a large majority of the population. This does not mean that archaeological materials should not be excavated, but that their conservation is considered a priority not always related to social enjoyment connected to a physical contact with the heritage.

In countries such as Greece and the Netherlands, the NEARCH survey showed that the public are not very interested in an active engagement in archaeological activities. In the Netherlands, it seems that there is a growing distance between the archaeological heritage sector and society; while 28 per cent of the respondents showed no engagement with archaeology in 1995, twenty years later this had grown to 48 per cent! In 1996 archaeology was not popular among 43 per cent of respondents, while in 2015 this was 48 per cent. Yet, more people would like to be involved: 35 per cent showed an interest in visiting an excavation in 1996, against 43 per cent in 2015.

In Greece, the visibility of archaeology is high (more than 90 per cent have visited an archaeological site, landscape, or monument) but people do not typically take part in archaeological actions such as excavations, conferences, or festivals. The notion of archaeology as greatly valued and useful follows the national narrative about archaeology, but the high value of archaeology and its usefulness is not recognized by the people in terms of experiencing material culture as part of everyday life (Kotsakis et al., 2015).

\section{Conclusions AND OuTlook}

For the past decade, archaeology has sought to address new challenges. The global 
economic crisis of 2008, followed by the gradual decline of preventive archaeology and subsequent archaeological unemployment, as well as the growing number of amateurs working with metal detectors have all been factors, but the primary challenge of showing archaeology as socially relevant and necessary demands that archaeologists change their attitude towards archaeological practice. Thus, more attention has been directed towards meeting societal needs and public expectations. While archaeologists have begun opening up their practice more widely through stronger engagement within the public and community archaeology domains, the NEARCH survey and the previous studies discussed indicate that this is still only beginning in most European countries (see van den Dries, 2015).

The very positive result of the survey is that archaeology is seen as socially valuable and that most Europeans maintain positive attitudes towards its development and investment. However, the need to better disseminate archaeological information and cultural heritage was clearly indicated by the public in all surveyed countries. The democratization of knowledge is an important aspect of archaeology because archaeologists, and the ethics frameworks in which they work, are obligated to share this knowledge as part of the public good associated with undertaking science (Moshenska, 2013: 212). But democratization requires outreach activities that reach diverse audiences. As the NEARCH and other surveys reveal (van den Dries, 2015), ethnic minorities as well as people with lower incomes are still not being reached by archaeologists and heritage managers. An inclusive archaeology which appreciates various voices and different needs is required; society needs not only more information but also greater opportunities to engage in archaeological projects. The dissemination of knowledge as well as opportunities to participate in archaeological events continue to be a challenge which the archaeological community must address to ensure its sustainability.

The next significant result concerns the issue of heritage policy found in some European countries (Willems, 2014). In general, there are strong indications that most Europeans believe it is the role of the State to manage and finance archaeology. It shows that society still expects national and local governments to support archaeology, and that it is a State's role to take care of its heritage.

Another important result is that archaeology is seen to be useful for understanding present and future global problems. This places archaeology in line with the sustainable development domain, in which science shares its achievements to resolve growing social and environmental issues. In this way, the past and heritage are not viewed as static and bygone, but as connected to the present. As suggested by Harrison (2013), sustainability of cultural heritage means broadening the 'field' to encompass a range of other social, political, economic, and environmental concerns, as well as the connections between them. The $\mathrm{NEARCH}$ survey clearly indicates that European society needs and expects archaeology to broaden its concerns.

We can conclude from these results that archaeology and cultural heritage management needs to work harder to reach a wider range of audiences. New, more inclusive, and future-oriented perspectives are needed, relating in particular to archaeology and the quality of life. The $\mathrm{NEARCH}$ project continues to develop ways to convey archaeology and the ways in which society may engage with it.

\section{Acknowledgements}

NEARCH (http://www.nearch.eu) has been funded with the support of the 
European Commission. This publication reflects the views of the authors only, and the Commission cannot be held responsible for any use which may be made of the information contained therein. The full results of the NEARCH survey are available online on the NEARCH archive, at http://dx.doi.org/10.5284/1041589. We thank Delphine Martelli-Banégas, Isabelle Panhard, and Tiphaine Favré from Harris Interactive for their involvement and their patience in the NEARCH poll survey.

\section{REFERENCES}

Abel, T., Abraham, A. \& Sommerhalder, K. 2010. Landscape and Well-being: A Scoping Study on the Health-promoting Impact of Outdoor Environments. International Journal of Public Health, 55: 59-69.

Agenda Kulturarv 2004. Slutrapport [Final Report] Agenda Kulturarv. Stockholm: Riksantikvarieämbetet [online] [accessed 19 May 2016]. Available at: <http://agendakulturarv.raa.se/opencms/export/agendakulturarv/dokument/Arkiv/Slutver.slutrap1.pdf>

Almansa, J. 2006. La imagen popular de la arqueología en Madrid. Arqueoweb, 8(1) [online] [accessed 10 May 2016]. Available at: <http://pendientedemigracion. ucm.es/info/arqueoweb/pdf/8-1/almansa. pdf>

Aronsson, P. 2003. Att förnya kulturarvet [Renewing the Heritage]. In: Agenda Kulturarv: Inspiration, Discussion. Stockholm: Agenda Kulturarv och Riksantikvarieämbetet, pp. 68-80.

Baxter, I. 2009. Means Maketh the End. The Context for the Development of Methodologies to Assess the State of the Historic Environment in the UK. In: M. L. Stig Sörensen \& J. Carman, eds. Heritage Studies: Methods and Approaches. London: Routledge, pp. 85-102.

Blank, Y. 2003. Delaktighetsmålet i Länsstyrelsepraktiken [Participation as an Objective in County Practice], Rapport 2003:3. Gothenburg: Länsstyrelsen Västra Götaland, Kulturmiljöenheten.
Bohne, A. \& Heinrich, M.U. 2000. Das Bild der Archäologie in der Öffentlichkeit: Eine Befragung in Bonn und Köln. Mitteilungen des Deutschen ArchäologenVerbandes, 31(2): 1-34.

Centro Studi TCI 2002. Metodo e strumenti per un osservatorio del turismo culturale. Il caso Basilicata. Milano: Touring Club Italiano.

Depaepe, P. \& Salas Rossenbach, K. 2013. Preventive Archaeology in France, Review and Point of View. In: M.P. Guermandi \& K. Salas-Rossenbach, eds. Twenty Years after Malta: Preventive Archaeology in Europe and in Italy. Bologna: IBC, pp. 129-36.

De Sars, F. \& Cambe, G. 2010. Image de l'archéologie auprès du grand public. Étude $n^{\circ}$ 10-0500390-01. Ipsos Marketing [online] [accessed 1 July 2016]. Available at: <http:// www.ipsos.fr/sites/default/files/attachments/ image_de_larcheologie_aupres_du_grand_ public.pdf>

Dezellus, J. \& Germain, F. 2014. Synthèse bibliographique: les publics et les médiations de l'archéologie. Paris: Département de la politique des publics, direction générale des patrimoines, Ministère de la Culture et de la Communication.

English Heritage 2000. Power of Place. The Future of the Historic Environment. London: Power of Place Office.

Eogan, J. 2010. The Impact of the Recession on Archaeology in the Republic of Ireland. In: N. Schlanger \& K. Aitchison, eds. Archaeology and the Global Economic Crisis. Multiple Impacts, Possible Solutions. Tervuren: Culture Lab Editions, pp. 19-24.

Erbani, F. 2015. Pompei. Italia. Milano: Feltrinelli.

García, J. 2012. Opinión frente a la conservación del patrimonio histórico-cultural. In: Conocimiento y percepción del patrimonio histórico en la sociedad española. Estudios de patrimonio 2. Madrid: Caja Madrid Fundación, pp. 65-99.

Harrison, R. 2013. Forgetting to Remember, Remembering to Forget: Late Modern Heritage Practices, Sustainability and the 'Crisis' of Accumulation. International Journal of Heritage Studies, 19: 579-95.

Hodder, I. 2010. Cultural Heritage Rights: From Ownership and Descent to Justice and Well-being. Anthropological Quarterly, 83: 861-82.

Hodder, I. \& Doughty, L. 2007. Mediterranean Prehistoric Heritage: Training, Education and 
Management. Cambridge: McDonald Institute for Archaeological Research.

Högberg, A. 2007. The Past in the Present: Prehistory and Preservation from a Children's Point of View. Public Archaeology, 6: 28-46.

Ibáñez, M. 2013. El patrimonio arqueológico de Sevilla, una reflexión desde la arqueología pública. PH Investigación, 1 (December): 89-107 [online] [accessed 10 May 2016]. Available at: <http://www.iaph. es/phinvestigacion/index.php/phinvestigacion/article/view/10\#.VzG_jOQat6I>

Incipit 2014. Executive Summary of the Project on the Social Value of Altamira. Programa de Investigación para la Conservación Preventiva y Régimen de acceso a la Cueva de Altamira. Memoria final. Ministerio de Educación, Cultura y Deporte [online] [accessed 10 May 2016]. Available at: <http://digital.csic.es/ bitstream/10261/112865/3/Executive_ Summary_Social_Value_def.pdf>

Jonchery, A. \& Dezellus, J. 2014. A l'écoute des visiteurs de l'archéologie: état des lieux et résultats d'enquête. L'archéologie à la rencontre des publics, Transmission et médiation des résultats de la recherche, colloque 26-27 novembre 2014. Paris: Ministère de la Culture et de la Communication [online] [accessed 29 March 2016]. Available at: <http://www. culturecommunication.gouv.fr/Politiquesministerielles/Archeologie/Rencontre-despublics/Les-publics-face-a-leur-passe>

Kaeser, M.A. 2016. La médiation de l'archéologie. Ethique de la complaisance ou impératif épistémologique? In Situ, 28 [online] [accessed 29 March 2016]. Available at: <http://insitu.revues.org/ 12814>; doi:10.4000/insitu.12814

Kajda, K. \& Kostyrko, M. 2016. Contemporary Heritage Promotion: Towards Socially Engaged Archaeology. Sprawozdania Archeologiczne, 68: 9-23.

Kajda, K., Michalik, T. \& Kobiałka, D. 2015. Heritage for All. A Contribution to the Inclusion of People with Intellectual Disabilities in Archaeology: A Polish Perspective. Current Swedish Archaeology, 23: 131-56.

Kobyliński, Z. 2009. Archeologia wobec wyzwań współczesności [Archaeology Facing Contemporary Challenges]. In: M. Brzostowicz, ed. Archeologia polska i jej czasy [Polish Archaeology and its times]. Poznań: Wydawnictwo PTPN, pp. 10331.

Kotsakis, K., Vokotopoulos, L., Lekka, A. \&

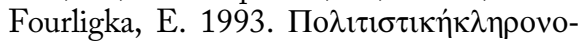

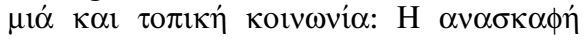

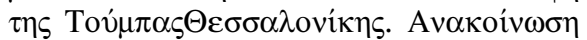

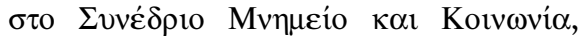

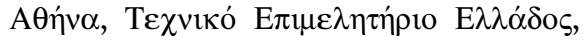
$1 \Delta \varepsilon \kappa \varepsilon \mu \beta p i ́ o v 1993$ [Cultural Heritage and Local Community: The Excavation of Toumba in Thessaloniki]. Paper presented at the Conference, Monument and Society, organised by the Technical Chamber of Greece, 1 December 1993, Athens.

Kotsakis, K., Kaukoula, K., Nanoglou, S. \& Astreinidou, P. 2007. Paliambela Management Plan. In: I. Hodder \& L. Doughty, eds. Mediterranean Prehistoric Heritage: Training, Education and Management. Cambridge: McDonald Institute for Archaeological Research. CD content.

Kotsakis, K., Kasvikis, K. \& Theodoroudi, E. 2015. Twenty Years After: Community Attitudes and Perceptions of Archaeology. Paper Presented at the 21st Annual Meeting of the European Association of Archaeologists (EAA), Glasgow, 2-5 September.

Kozioł, A., Trelka, M. \& Florjanowicz, P. 2013. Spoteczno-gospodarcze oddziatywanie dziedzictwa kulturowego. Raport z badan spotecznych [The Socio-Economic Impact of the Cultural Heritage. A Social Research Report]. Warszawa: Narodowy Instytut Dziedzictwa [online] [accessed 5 May 2016]. Available at: <http://www.nid.pl/pl/ Informacje_ogolne/Aktualnosci/news.php? $\mathrm{ID}=2150>$

Madsuda, A. \& Okamura, K. eds. 2011. New Perspectives in Global Public Archaeology. New York: Springer.

Marciniak, A. 2011. Contemporary Polish Archaeology in Global Context. In: L.R. Lozny, ed. Comparative Archaeologies: A Sociological View of the Science of the Past. New York: Springer, pp. 179-94.

Marciniak, A. 2015. The Aftermath of Malta. In: M.H. van Dries, S.J. van der Linde \& A. Strecker, eds. Fernweh. Crossing Borders and Connecting People in Archaeological Heritage Management. Essays in Honour of Prof. Willem J.H. Willems. Leiden: Sidestone Press, pp. 34-37. 
Marciniak, A. \& Pawleta, M. 2010. Archaeology in Crisis: The Case of Poland. In: N. Schlanger \& K. Aitchison, eds. Archaeology and the Global Economic Crisis: Multiple Impacts, Possible Solutions. Tervuren: Culture Lab Editions, pp. 87-96.

Marciniak, A., Minta-Tworzowska, D. \& Pawleta, M. eds. 2011. Wspótczesne oblicza przesztości [Contemporary Faces of the Past]. Poznań: Wydawnictwo Poznańskie.

Martelli-Banégas, D, Panhard, I. \& Favré, T. 2015. Image of Archaeology in Europe: Summary Report General Public. Harris Interactive [online] [accessed 20 April 2017]. Available at: <http://archaeologydataservice.ac. uk/archives/view/nearch_2017/landing.cfm>

Merriman, N. ed. 2004. Public Archaeology. London: Routledge.

MIBACT 2014. Minicifre della Cultura. Roma: Gangemi Editore [online] [accessed 10 May 2016]. Available at: <http://www. ufficiostudi.beniculturali.it/mibac/multimedia/ UfficioStudi/documents/1425902120318_ Minicifre_2014_bassa_risoluzione.pdf>

MIBACT 2016. Musei, monumenti e aree archeologiche statali. Rilevazione 2015. Roma: Ministero dei beni e delle attività culturali e del Turismo [online] [accessed 10 May 2016]. Available at: <http://www. beniculturali.it $/ \mathrm{mibac} /$ multimedia/MiBAC/ documents/1452786836128_2015Musei PerSito.pdf>

Montanari, T. 2015. Privati del Patrimonio. Torino: Einaudi.

MORI 2000a. Attitudes Towards the Heritage: Research Study Conducted for English Heritage. London: English Heritage.

MORI 2000b. What Does 'Heritage' Mean to You? [online] [accessed 10 May 2016]. Available at: <https://www.ipsos-mori.com/ researchpublications/researcharchive/1558/ What-Does-Heritage-Mean-To-You.aspx>

MORI 2003. Making Heritage Count? Research Study Conducted for English Heritage, Department for Culture, Media and Sport and the Heritage Lottery Fund. London: English Heritage.

Moshenska, G. 2013. The Archaeological Gaze. In: A. González-Ruibal, ed. Reclaiming Archaeology: Beyond the Tropes of Modernity. London: Routledge, pp. 211-19.

NIPO/AIC 1996. Samenvatting Bevolkingsonderzoek 'archeologie' [Summary Population Study 'Archaeology'] (Archeologisch Informatie Cahier 10). Leiden: Archaeologisch Informatie Centrum.
Olivier, A. 2015. Challenging AttitudesDelivering Public Benefit. In: P. Florjanowicz, ed. When Valletta meets Faro. The Reality of European Archaeology in the $21^{\text {st }}$ Century. Proceedings of the International Conference Lisbon, Portugal, 19-21 March 2015 (EAC Occasional Paper 11). Namur: Europae Archaeologia Consilium, pp. 13-23.

Parga-Dans, E. 2010. Commercial Archaeology in Spain: Its Growth, Development and the Impact of the Global Economic Crisis. In: N. Schlanger \& K. Aitchison, eds. Archaeology and the Global Economic Crisis: Multiple Impacts, Possible Solutions. Tervuren: Culture Lab Editions, pp. 45-54.

Parga-Dans, E. 2014. Informe sociológico. Anexo I: Informe descriptivo de la encuesta de valoración de la visita. Programa de Investigación para la Conservación Preventiva y Régimen de acceso a la Cueva de Altamira. Memoria final. Ministerio de Educación, Cultura y Deporte [online] [accessed 10 May 2016]. Available at: <http://digital. csic.es/bitstream/10261/113130/3/Anexo_ I_informe_descriptivo_valoracion_visita.pdf>

Pawleta, M. 2016. Przesztośśc we wspót czesności. Studium metodologiczne archeologicznie kreowanej przesztósci w przestrzeni spotecznej [The Past in the Present. Methodological Study of the Creation of the Archaeological Past in the Social Sphere]. Poznan: Wydawnictwo Naukowe UAM.

RAÄ (Riksantikvarieämbetet) 2002. Kommentarer till statistiska centralbyråns slutrapport mars 2002: Vad betyder kulturmiljön for dig? [Comments on the Central Statistical Office's Final Report of March 2002: What Does the Cultural Environment Mean to You?]. Stockholm: Riksantikvarieämbetet.

Sakellariadi, A. 2011. Archaeology for the People? Greek Archaeology and its Public: An Analysis of the Socio-political and Economic Role of Archaeology in Greece (unpublished doctoral dissertation, University College London).

Salmona, P. 2008. Le rébus au fond du labyrinthe. Archéopages, Hors-série, 1: 120-23.

Schlanger, N. \& Aitchison, K. 2010. Archaeology and the Global Economic Crisis: Multiple Impacts, Possible Solutions. Trevuren: Culture Lab Editions.

Solima, L. 2000. Il pubblico dei musei. Indagine sulla comunicazione nei musei statali italiani. Roma: Gangemi Editore. 
Stroulia, A. \& Sutton, S.B. eds. 2010. Archaeology in Situ: Sites, Archaeology, and Communities in Greece. Lanham (MD): Rowman \& Littlefield.

Synnestvedt, A. 2008. Fornlämningsplatsen. Kärleksaffär eller trist historia [Heritage Sites - A Love Affair or a Sad Story] (unpublished $\mathrm{PhD}$ dissertation, University of Gothenburg). van den Dries, M.H. 2014. Community Archaeology in the Netherlands. Journal of Community Archaeology and Heritage, 1: 69-88.

van den Dries, M.H. 2015. From Malta to Faro, How Far Have We Come? Some Facts and Figures on Public Engagement in the Archaeological Sector in Europe. In: P.A.C. Schut, D. Scharff \& L. de Wit, eds. Setting the Agenda: Giving New Meaning to the European Archaeological Heritage (EAC Occasional Paper 10). Namur: Europae Archaeologia Consilium, pp. 45-55.

van den Dries, M.H. \& van der Linde, S.J. 2012. Twenty Years after Malta: Archaeological Heritage as a Source of Collective Memory and Scientific Study Anno 2012. Analecta Prehistorica Leidensia, 43/44: 9-19.

van den Dries, M.H., Boom, K.H.J. \& Van der Linde, S.J. 2015. Exploring Archaeology's Social Values for Present-day Society. Analecta Prehistorica Leidensia, 45: 221-34.

Willems, W.J.H. 2014. The Future of World Heritage and the Emergence of Transnational Heritage Regimes. Heritage E' Society, 7: 105-20.

\section{Biographical Notes}

Kornelia Kajda is an archaeologist and anthropologist working at the Institute of Archaeology at Adam Mickiewicz University in Poznań. Her primary research interests focus on the archaeology of the contemporary past, especially the archaeology of the Second World War and PostSoviet era in Poland. Her expertize is also in public archaeology and inclusive archaeology projects.

Address: Department of History, Adam Mickiewicz University in Poznań, ul.
Umultowska 89D, 61-614 Poznań, Poland. [email: korkajda@amu.edu.pl]

Amala Marx has an MA from the Ecole Pratiques des Hautes Etudes in Paris. Since 2011, she has been assisting the Head of the international Department at the French National Institute for Preventive Archaeological Research in developing the international relations of the institute; she is also in charge of the training of overseas archaeologists and heritage professionals.

Address: Institut national de recherches archéologiques préventives, 121 rue de Madrid, 75014, Paris, France. [email: amala.marx@inrap.fr]

Holly Wright is European Projects Manager at the Archaeology Data Service (ADS); a national archive for archaeological data in the UK (http://archaeologydataservice.ac.uk), based in the Department of Archaeology, at the University of York. Her research focuses on field drawing, vector graphics, visualization, Web design, Web standards, and the Semantic Web in archaeology.

Address: Archaeology Data Service, Department of Archaeology, University of York, King's Manor, York YO1 7EP, UK. [email: holly.wright@york.ac.uk]

Julian Richards is a Professor of Archaeology at the University of York. He is Director of the Centre for Digital Heritage, Director of the Archaeology Data Service, and, since October 2013, Director of the White Rose College of the Arts and Humanities.

Address: Archaeology Data Service, Department of Archaeology, University of 
York, King's Manor, York YO1 7EP, UK. [email: julian.richards@york.ac.uk]

Arkadiusz Marciniak is a Professor of Archaeology at Adam Mickiewicz University of Poznań in Poland. His expertize is in the development of early farming communities in western Asia and central Europe and their progression to complex societies. His other interests comprise zooarchaeology of farming communities, archaeological heritage, and the political context of practicing archaeology as well as archaeological theory and history of archaeological thought.

Address: Department of History, Adam Mickiewicz University in Poznan, ul. Umultowska 89D, 61-614 Poznan, Poland. [email: arekmar@amu.edu.pl]

Kai Salas Rossenbach has an MA in archaeology from the University of Paris 1 Pantheon-Sorbonne, and over ten years of experience in the heritage sector. Since 2011, he has been Head of the international Department of the French National Institute for Preventive Archaeological Research.

Address: Institut national de recherches archéologiques préventives, 121 rue de Madrid 75014 Paris, France. [email: kai. salas-rossenbach@inrap.fr]

Michal Pawleta is Assistant Professor at the Institute of Archaeology at Adam Mickiewicz University in Poznań. His research interests include theory and methodology of archaeology, social archaeology, public archaeology, archaeological education and popularization as well as social significance of the past and archaeological heritage and assessment of their current values.
Address: Department of History, Adam Mickiewicz University in Poznań, ul. Umultowska 89D, 61-614 Poznań, Poland. [email: mpawleta@amu.edu.pl]

Monique H. van den Dries is Associate Professor in archaeological heritage management at the Faculty of Archaeology, Leiden University. Her research interests include heritage management policies and their impact on the archaeological discipline and profession, public engagement, and the assessment of societal values and impacts of archaeology, such as on wellbeing and quality of life.

Address: Department of Archaeology, Leiden University, Rapenburg 70, 2311 EZ Leiden, Netherlands. [email: m.h.van. den.dries@arch.leidenuniv.nl]

Krijn Boom is a $\mathrm{PhD}$ researcher at Leiden University. His research focuses on the impact of archaeological activities and on how this impact in (local) communities can be measured and quantified.

Address: Department of Archaeology, Leiden University, Rapenburg 70, 2311 EZ Leiden, Netherlands. [email: boom@ arch.leidenuniv.nl]

Maria Pia Guermandi is a Classical archaeologist. Since 1987 she has worked at the Istituto Beni Culturali of Regione Emilia Romagna where she is currently responsible for Geographical Information Systems in Cultural Heritage.

Address: Institute for Cultural and Natural Heritage, Via Galliera 21, 40121 Bologna, Italy. [email: mpguermandi@regione.emiliaromagna.it] 
Felipe Criado-Boado is Research Professor at the CSIC and Director of Incipit (Institute of Heritage Sciences). He is currently President of the European Association of Archaeologists. His major areas of expertize are landscape archaeology (mostly dealing with megalithism and the origins of monumental architecture, rock art, and the formation of peasant landscapes) and archaeological theory (with a special interest in interpretive theory, critical heritage studies, and public science).

Address: Institute of Heritage Sciences, Avda. de Vigo s/n, 15705 Santiago de Compostela, Spain. [email: felipe.criadoboado@incipit.csic.es]

David Barreiro is a staff technician and researcher at the Incipit (CSIC Institute of Heritage Sciences, based on Santiago de Compostela, Spain). His areas of interest relate to the social condition of archaeology, the geographical and archaeological analysis of heritage, and the ways of enhancement and socialization of heritage.

Address: Institute of Heritage Sciences, Avda. de Vigo s/n, 15705 Santiago de Compostela, Spain. [email: david.barreiro@incipit.csic.es]

Anita Synnestvedt holds a $\mathrm{PhD}$ in archaeology with impact on heritage issues. Her main research interests are in heritage, art and archaeology, contemporary archaeology, and pedagogy. Since 2014, she has been active as the coordinator of the Cultural Heritage Academy at the University of Gothenburg.

Address: Department of Historical Studies, University of Gothenburg, Renströmsgatan 6, 40530 Gothenburg, Sweden. [email: anita.synnestvedt@archaeology.gu.se]
Kostantinos Kotsakis is Professor of Prehistoric Archaeology at the Department of Archaeology of the Aristotle University of Thessaloniki. His main research topics are archaeological theory and method, history of Greek archaeology, and Aegean material culture, as well as public archaeology and heritage management.

Address: Department of Archaeology, Aristotle University of Thessaloniki, University Campus 54124, Thessaloniki, Greece. [email: kotsakis@hist.auth.gr]

Kostantinos Kasvikis is an Assistant Professor of history didactics and culture education in the Department of Primary Education, at the University of Western Macedonia. His research interests and teaching topics are: history didactics, museum education, textbooks research, public archaeology, and the politics of the past.

Address: P1. Department of Primary Education, Florina, the University of Western Macedonia, Agiou Dimitriou, Kozani 501 00, Greece. [email: kkasvikis@ uowm.gr]

Eleftheria Theodoroudi is an archaeologistmuseologist and a $\mathrm{PhD}$ candidate at the Aristotle University of Thessaloniki. Her thesis is on identities and material culture in Early Iron Age Macedonia, Greece. Her research interests are in the Iron Age archaeology of the Aegean, analytical methods in archaeology, theoretical archaeology, public archaeology, and heritage management.

Address: Department of Archaeology, Aristotle University of Thessaloniki, University Campus 54124, Thessaloniki, Greece. [email: eletheod@hist.auth.gr] 
Friedrich Lüth studied Pre- and Archaeology at the Technical University of Protohistory, Near Eastern Archaeology, Berlin. and Ethnology at the Universities of Saarbrücken and Hamburg. Between 2006 and 2011, he was Director of the RomanGermanic Commission of the German Archaeological Institute in Frankfurt. Since 2011, he has served as Director and Professor at the headquarters of the German Archaeological Institute, responsible for Cultural Heritage Management.

Address: German Archaeological Institute (DAI), Podbielskiallee 69-71, 14195 Berlin, Germany. [email: friedrich.lueth@dainst.de]

Mayssoun Issa studied architecture, history of architecture, building archaeology and heritage conservation in Latakia, Damascus, and Berlin. She is currently a doctoral candidate in the Department of Building

Address: German Archaeological Institute (DAI), Podbielskiallee 69-71, 14195 Berlin, Germany. [email: mayssoun.issa@dainst.de]

Isabelle Frase studied architecture at the Berlin Institute of Technology (TU). Since 2008 she has cooperated with the Chair of Building Archaeology as well as the Chair for Urban and Regional Planning at the TU Berlin in different research projects, and, since 2009 , she has worked on her doctoral thesis entitled 'Collegium Augusteum in Wittenberg'.

Address: German Archaeological Institute (DAI), Podbielskiallee 69-71, 14195 Berlin, Germany. [email: isabelle.frase@ gmail.com]

\section{Archéologie, patrimoine et rôle social : perception de l'archéologie européenne par le grand public}

Cet article présente les principaux résultats d'une grande enquête conduite dans le cadre du projet NEARCH sur la perception qu'a le public européen de l'archéologie et du patrimoine. L'analyse se concentre sur trois aspects d'importance pour la pratique contemporaine de l'archéologie. Le premier concerne l'image qu'a le grand public de l'archéologie et la définition qu'il en donne. Le second a trait aux valeurs que l'archéologie représente pour ce public. Le troisième porte sur les attentes de la société envers les archéologues et l'archéologie. L'enquête du projet NEARCH démontre clairement qu'il existe une forte demande du public européen pour la contribution de l'archéologie à de nombreux domaines, et pour une gestion du patrimoine culturel impliquant plus fortement les différents groupes intéressés par l'archéologie et le patrimoine. Translation by Amala Marx

Mots clefs: engagement social, sondage européen, projet $\mathrm{NEARCH}$

\section{Archäologie, Bodendenkmalpflege und sozialer Wert: die Ansichten der Öffentlichkeit über die Archäologie in Europa}

In diesem Artikel werden die wesentlichen Ergebnisse einer Umfrage, die im Rahmen des NEARCH Projektes durchgeführt wurde, vorgestellt. Unsere Untersuchung betrifft drei Hauptpunkte, die von großer Bedeutung für die heutige Praxis der Archäologie sind. Erstens betrachten wir, wie sich die Öffentlichkeit die Archäologie vorstellt. Zweitens befassen wir uns mit den Werten, für welche die Archäologie in der öffentlichen Wahrnehmung steht. Und drittens untersuchen wir die sozialen Erwartungen, die in die Archäologie und den Archäologen gesetzt werden. Die NEARCH Umfrage 
zeigt deutlich, dass die Europäer viel von der Archäologie erwarten, und zwar in einem breiten Spektrum von Bereichen, und dass die Bodendenkmalpflege allgemein mit den verschiedenen archäologischen und kulturerblichen Gruppen konstruktiver zusammenarbeiten muss. Translation by Madeleine Hummler

Stichworte: öffentliche Archäologie, soziales Engagement, europäische Umfrage, NEARCH Projekt 